\title{
The potential impacts of climate change and variability on forests and forestry in the Mid-Atlantic Region
}

\author{
M ary M cKenney-Easterling 1,*, David R. DeWalle², Louis R. Iverson ${ }^{3}$, \\ Anantha M. Prasad ${ }^{3}$, A nthony R. Buda ${ }^{2}$
}

${ }^{1} \mathrm{C}$ enter for Integrated Regional Assessment, and ${ }^{2}$ School of Forest Resources, The Pennsylvania State University, University Park, Pennsylvania 16802, USA

${ }^{3} \mathrm{~N}$ ortheastern Research Station, US Department of A griculture Forest Service, 359 Main Road, Delaware, Ohio 43015, USA

\begin{abstract}
As part of the Mid-Atlantic Regional Assessment, an evaluation is being made of the impacts of climate variability and potential future climate change on forests and forestry in the MidAtlantic Region. This paper provides a brief overview of the current status of forests in the region, and then focuses on 2 components of this evaluation: (1) modeling of the potential impacts of climate change on tree species' distributions, and (2) a survey of how extreme weather events affect forests and forest land management in the region. The tree distribution modeling indicates that climate change may result in large increases in the amount of forest dominated by oak and pine, and large decreases in maple/beech/birch forest, assuming that trees are able to migrate in pace with climate change. The forest management survey results suggest that the major impacts of severe weather on forest operations currently are related more to extreme precipitation and high wind events than to temperature extremes. The implications of these results for future climate change are discussed.
\end{abstract}

KEY WORDS: Forests · Climate change · Species distribution · Forest management · M id-Atlantic Region

\section{INTRODUCTION}

Forests are the dominant land cover of the MidAtlantic Region (MAR), accounting for about $65 \%$ of total land area (US EPA 1997). As such, they shape the landscape and provide numerous ecological, economic, aesthetic, hydrologic and recreational benefits to this highly populated region. As part of the Mid-Atlantic Regional Assessment (MARA) we are examining the impacts of climate variability -in particular, severe weather events-and potential future climate change on the region's forests. We distinguish 2 types of climate impacts (1) the long-term impacts of changing temperature and precipitation regimes on the growth and development of trees, including changes in species composition, and (2) shorter-term impacts of extreme weather events which can cause direct damage to trees and modifications to forest land manage-

*E-mail: mme@essc.psu.edu ment practices. In order to address the long-term impacts of climate change, we applied statistical models developed as part of a previous study (Iverson \& Prasad 1998) to predict potential changes in species composition in Mid-Atlantic forests using projections of climate change from 5 different general circulation models (GCMs). A survey of the current impacts of severe weather on forest land management in the MAR was used to gain insight into the importance of severe weather now, and how any future changes in severe weather would likely affect forests and forest land management. After providing some background information on forests of the region, this paper focuses on these 2 components of the study.

\section{CURRENT STATUS OF MID-ATLANTIC FORESTS}

Forests in the MAR support a rich mix of tree species, from the pine and coastal wetland regions in the south 
to the northern upland hardwoods. In terms of current volumes of growing stock, dominant hardwood species are red oaks, white oak, yellow-poplar, red maple, sugar maple, black cherry, beech and sweetgum. Softwood forests are dominated by loblolly, shortleaf and white pines, and hemlock (Powell et al. 1994). Many other species are locally abundant. The region's dominant forest types are oak-hickory ( $46 \%$ of forested area) and maple-beech-birch (37\% of area), followed by pine and mixed pine-hardwood forests ( $8 \%$ of area) (Fig. 1).

Forests in the region were extensively cut for wood products in the early 1900s. Active management and protection from fire since then has resulted in secondgrowth forests that are rapidly approaching maturity. Recent survey data indicate that forest area in the M idA tlantic states has been relatively stable over the past $30 \mathrm{yr}$, decreasing very slowly by about $1 \%$ decade $^{-1}$ (Powell et al. 1994). Although forested area has changed little over this period, total standing biomass has increased due to an increase in biomass per unit area. Net volume of hardwood growing stock is steadily increasing, although growth rates are slowing as the forests approach maturity. Softwood growing stock volumes have leveled off somewhat and are expanding only very slowly. The ratio of net growth (growth minus mortality) to removals is 2.2 for hardwoods and 1.3 for softwoods (Powell et al. 1994).

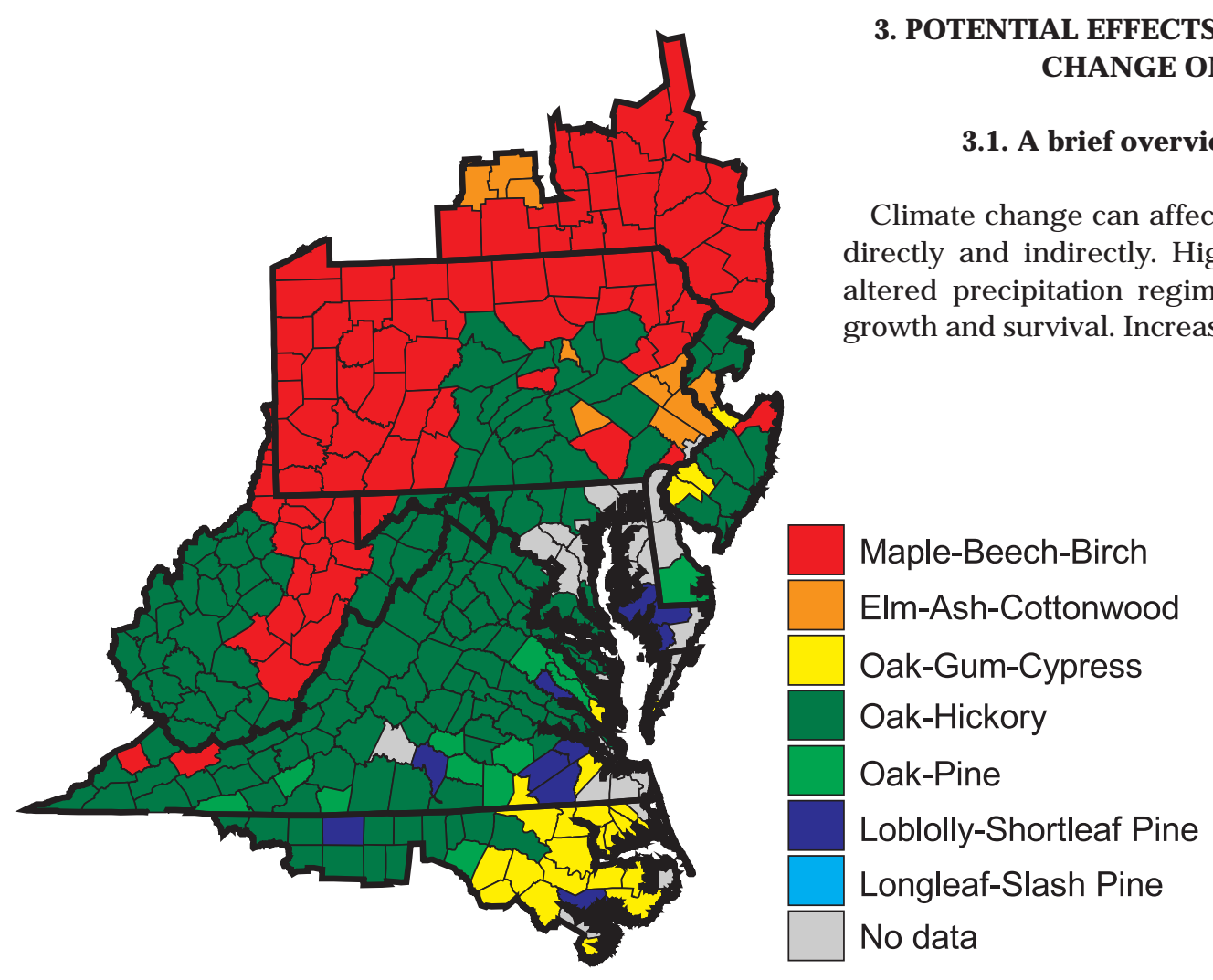

Forests provide important market and non-market benefits to the MAR. The region's primary forest products are sawlogs, pulpwood, fuelwood, and veneer logs (Powell et al. 1994). Although forest-related sectors represent only $2.5 \%$ of the region's total gross economic output, this small percentage understates the role of these sectors in the economy (Rose et al. 2000, in this issue). First, these sectors stimulate additional production and employment in supplier and customer sectors. Second, forests provide a base for hunting, camping, hiking, birdwatching and fishing, which contribute to the service and other sectors of the economy. Economically, forest-related sectors are highly interdependent both within the region and with the rest of the US (Rose et al. 2000). Mid-Atlantic forests are also highly valued for the non-market benefits they provide, including watershed and riparian buffers, wildlife habitat, enhanced biodiversity, carbon sequestration, and aesthetic appeal.

Forests in the MAR are currently stressed by natural and anthropogenic factors: disease and insects (especially the gypsy moth), deer browsing, atmospheric pollution (deposition of acidic compounds and high ground levels of ozone), and, occasionally, wildfire. Increased urban/suburban development contributes to increased fragmentation of forest tracts, reducing the ability of plants and animals to survive and migrate.

\section{POTENTIAL EFFECTS OF FUTURE CLIMATE CHANGE ON FORESTS}

\subsection{A brief overview of key impacts}

Climate change can affect Mid-Atlantic forests both directly and indirectly. Higher temperatures and an altered precipitation regime will directly affect tree growth and survival. Increased concentrations of atmo-

Fig. 1. Distribution of major forest types in the Mid-Atlantic Region. (Based upon Forest Inventory and A nalysis [FIA] data collected by USDA, Forest Service and compiled by Iverson et al. [1996]) 
spheric $\mathrm{CO}_{2}$ may cause enhanced growth and greater efficiency of water use, though it is uncertain whether these effects will persist under field conditions (Bazzaz 1990, Eamus 1996). Forests may be indirectly impacted by factors that are themselves affected by changes in climate and atmospheric constituents, such as the distribution and abundance of pests, fire frequency, and climate-sensitive soil processes such as erosion and decomposition (IPCC 1996). For example, pest species may expand their distributions northward and produce more generations annually if temperatures increase (IPCC 1996). Fires may become more frequent if conditions become dryer. Decomposition of soil organic matter will be enhanced with warmer temperatures, increasing nutrient availability (Melillo et al. 1993). The net effect of these direct and indirect impacts is difficult to predict, and will likely vary among species. This may alter competitive interactions and lead to shifts in species composition (Bazzaz et al. 1990). Impacts will be more severe if species are limited in their ability to migrate to a more climatically suitable habitat (Pitelka and the Plant Migration Workshop Group 1997, Soloman \& Kirilenko 1997).

Potential changes in the frequency of extreme weather events may also impact forests (Auclair et al. 1996), though relatively little attention has been given to these short-term phenomena in studies of climate change. The ways in which climate change may alter extreme events are very poorly understood, though evidence suggests that 'storminess' will increase in the MAR with greenhouse warming (Fisher et al. 1999). These short-term and spatially variable events are difficult to incorporate using traditional forest modeling approaches.

There have been a variety of prior efforts to assess the impacts of long-term climate change on forested ecosystems, though none have focused on the MAR in particular. Models-both empirical and mechanistic, static and dynamic, and at global to local scales-have been used to predict changes that might occur in the species composition and/or productivity of forests in response to climate change; some of these include the direct effects of $\mathrm{CO}_{2}$. Significant uncertainties are associated with these models, and with the GCMbased climate change scenarios that are typically used to drive them (IPCC 1998). Below we give a brief overview of some prior studies that have examined changes in species composition and/or forest productivity and include the MAR.

VEM AP (Vegetation/Ecosystem M odeling and Analysis Project) Phase 1 (VEMAP members 1995) compared the results of 3 biogeochemical models and 3 biogeographical models under a range of GCM-based climate change scenarios for the conterminous US. Under a $2 \times \mathrm{CO}_{2}$ climate and including the direct effects of a doubled $\mathrm{CO}_{2}$ atmosphere, the 3 biogeography models show warm-temperate mixed forest/evergreen forest moving northward (extent varies by GCM scenario), displacing temperate deciduous forest in the southern part of the MAR. Cool-temperate mixed forest disappears completely from the region. One of the models shows that some areas in western Virginia and central Pennsylvania become too dry to support forest and are converted to savanna-type vegetation. Without the direct effects of $\mathrm{CO}_{2}$, results are similar for 2 of the 3 models. The third predicts that savanna will replace much of the forested area in the MAR, especially under the warmer climate scenarios. When the 3 biogeochemical models were run with input from the biogeography models, there was considerable variation in net primary productivity (NPP) estimates among models and among GCM scenarios, although the net change in annual NPP appears to be positive for the MAR in all cases.

Forest succession (or 'gap') models have been applied to simulate transient changes in forest composition and biomass on representative plots (e.g., Soloman 1986, Pastor \& Post 1988, Shugart \& Smith 1996). Although few of these studies have included sites in the MAR, simulations for eastern deciduous forest have shown that tree species are affected differentially by climate change. These differential effects can cause shifts in species composition and/or forest dieback if species migrations are delayed (Soloman \& Kirilenko 1997). Early studies using gap models and relatively severe climate scenarios indicated the potential for extensive dieback of eastern forests (e.g., Soloman 1986, Pastor \& Post 1988). More recent results with improved forest and climate models have suggested that the earlier estimates may be too extreme (IPCC 1998). For the most part, these models do not include the potential direct effects of $\mathrm{CO}_{2}$ (Shugart \& Smith 1996).

Studies using a regional forest ecosystem model to estimate climate change impacts on NPP have suggested that forests in the northeastern US might increase in biomass (Aber et al. 1995), while southeastern forests could experience dieback ( $\mathrm{M}$ cNulty et al. 1996). However the northeastern study included the direct effects of $\mathrm{CO}_{2}$ while the southeastern one did not. This approach does not consider possible shifts in species' distributions.

\subsection{O ur modeling approach}

None of these prior assessments focused on the MAR in particular nor did they include regional estimates of species-specific changes. To fill this gap, we expanded upon a previous study of trees in the eastern US (Iver- 
son \& Prasad 1998) and applied our approach to the M AR using 5 GCM scenarios. The modeling approach uses a statistical procedure to relate current environmental conditions to current tree species' abundance at the county level, and then projects potential future abundance based on potential future climatic conditions. A statistical approach is justified based on the observation that environmental factors, modified by disturbance and competitive processes, generally control the overall range and abundance of tree species (Woodward 1987).

USDA Forest Service Forest Inventory and Analysis (FIA) data for over 100000 plots in the eastern US (Hansen et al. 1992) provided tree species range and abundance information. The data were summarized for individual forest plots to create general importance values (IV) for each species:

$$
\mathrm{IV}(\mathrm{x})=\frac{100 \mathrm{BA}(\mathrm{x})}{\mathrm{BA}(\text { all species) }}+\frac{100 \mathrm{NS}(\mathrm{x})}{\mathrm{NS}(\text { all species })}
$$

where $\mathrm{BA}=$ basal area and NS = number of stems. In single-species stands, the IV could thus reach the maximum of 200. The plots were averaged for each county to yield that county's IV score. Only those species that were found in at least 100 counties were modeled. Further details are given in Iverson et al. (1996).

Values of 33 environmental variables were obtained for each county in the US east of $100^{\circ} \mathrm{W}$. Climate datamonthly means of precipitation, temperature, and potential evapotranspiration (PET) - were obtained for current conditions, and from the output of 5 GCM s as specified below. These climate data were used to generate annual means of temperature and precipitation, mean monthly values of PET, and 2 derived attributes of physiological importance to tree growth for this region: J uly-August (the time most prone to drought stress) ratio of precipitation to potential evapotranspiration (J ARPPET), and $M$ ay to September (i.e., growing season) mean temperature (MAYSEPT). Additional environmental variables used in the models include 18 soil factors, 4 land use/cover variables, 3 elevation variables, and a measure of landscape fragmentation. Details and data sources for the environmental variables can be found in Iverson \& Prasad (1998).

Climate scenarios from $5 \mathrm{GCMs}$, based on equilibrium conditions and a doubling of $\mathrm{CO}_{2}$, were used to evaluate possible future species distributions: (1) the Geophysical Fluid Dynamics Laboratory (GFDL) model (Wetherald \& M anabe 1988); (2) the Goddard Institute of Space Studies (GISS) model (Hansen et al. 1988); (3) the Hadley Center for Climate Prediction and Research (Hadley) model (Mitchell et al. 1995); (4) the United Kingdom M eteorological Office (UKM O) model (Wilson \& Mitchell 1987); and (5) the Canadian Climate Center (CCC) model (Laprise et al. 1998). Cur- rent climate, GFDL, and GISS data were obtained in $10 \times 10 \mathrm{~km}$ format (US EPA 1993). Hadley, CCC, and UKM O data were obtained from the USDA Forest Service Laboratory in Corvallis, Oregon in $0.5 \times 0.5^{\circ}$ format (R. Neilson \& R. Drapek pers. comm.). ${ }^{1}$

These 5 scenarios give a range of possible outcomes in equilibrium climate at $2 \times \mathrm{CO}_{2}$ for the MAR (Table 1). ${ }^{2}$ The Hadley scenario has the least severe change in temperature, both on a mean annual basis $\left(+2.6^{\circ} \mathrm{C}\right)$ and for J uly and J anuary. The UKMO model predicts the most extreme change in mean annual and J anuary temperature $\left(+7.9\right.$ and $+8.9^{\circ} \mathrm{C}$, respectively), while J uly temperatures are highest under the GFDL scenario $\left(+8.4^{\circ} \mathrm{C}\right)$. Precipitation shows little change under the GISS, GFDL and CCC scenarios, while the Hadley model calls for a $26 \%$ increase in precipitation, and the UKMO model for a $15 \%$ increase. Conditions become much dryer relative to current conditions under all scenarios during the warmest months, as evidenced by the reduction in the ratio of J uly-August precipitation to PET from the current condition of J ARPPET $=1.34$.

Individual tree species models were generated using DISTRIB, a statistical model predicting the distribution and importance value of most of the common tree species in the Eastern United States (Iverson \& Prasad 1998). DISTRIB uses regression tree analysis (RTA) to capture spatial variation in the environmental variables that determine species' importance. RTA uses a recursive partitioning approach to first split a data set using a single variable. It then splits the remaining data into increasingly smaller, homogeneous subsets until a termination is reached (Clark \& Pregibon 1992). The variables that operate at larger scales (e.g., many climate variables) usually split the data early in the model, while variables that influence the response variable at more local scales

\footnotetext{
${ }^{1}$ Importantly, the latter 3 data sets had relatively high PET values as compared to the first 3 data sets (Table 1 ), because the method of PET computation differed between the 2 sources of data (R. Neilson pers. comm.). This inconsistency could potentially affect our results for the Hadley, CCC, and UKMO models for the species that use the variables PET or JARPPET in their models (these species are labeled in Table 3). However, we believe the impact is minimal because, in most of the models, the PET-related variable comes out low in the binary regression tree and, even for the 8 species where the PET variable comes out high in the regression tree, there appears to be consistency across the 5 GCM scenarios (see Table 3)

${ }^{2}$ For comparison with the transient GCM scenarios used in other portions of the MARA study, if greenhouse gases increase at a rate of $1 \% \mathrm{yr}^{-1}$ - as assumed in developing the transient climate scenarios - a doubling will occur in $71 \mathrm{yr}$, or by Year 2064. Equilibrium (e.g., $2 \times \mathrm{CO}_{2}$ ) GCM scenarios tend to predict larger temperature increases than transient scenarios at an equivalent $\mathrm{CO}_{2}$ level, due to the thermal inertia of oceans and other factors (Kattenberg et al. 1996)
} 
Table 1. Change from current climate conditions as predicted by $5 \mathrm{GCMS}$ ( $2 \times \mathrm{CO}_{2}$ equilibrium runs) for each climate variable in the Iverson-Prasad tree models (area-weighted averages for the MAR); actual value is shown for J ARP$P E T$. For reference, values for current climate are shown in last row of the table. AVGT: mean annual temperature $\left({ }^{\circ} \mathrm{C}\right)$; J ANT: mean J anuary temperature $\left({ }^{\circ} \mathrm{C}\right)$; J ULT: mean J uly temperature $\left({ }^{\circ} \mathrm{C}\right)$; PPT: mnnual precipitation $(\mathrm{mm})$; PET: potential evapotranspiration ( $\mathrm{mm} / \mathrm{mo}) ;$ MAYSEPT: mean May-September temperature $\left({ }^{\circ} \mathrm{C}\right)$; J ARPPET: J uly-A ugust ratio of precipitation to PET

\begin{tabular}{|lccccccc|}
\hline & $\begin{array}{c}\text { JANT } \\
\left({ }^{\circ} \mathrm{C}\right)\end{array}$ & $\begin{array}{c}\text { JULT } \\
\left({ }^{\circ} \mathrm{C}\right)\end{array}$ & $\begin{array}{c}\text { AVGT } \\
\left({ }^{\circ} \mathrm{C}\right)\end{array}$ & $\begin{array}{c}\text { MAYSEPT } \\
\left({ }^{\circ} \mathrm{C}\right)\end{array}$ & $\begin{array}{r}\text { PPT } \\
(\%)\end{array}$ & $\begin{array}{r}\text { PET } \\
(\%)\end{array}$ & J ARPPET \\
\hline GISS & +4.7 & +3.7 & +4.2 & +3.9 & +4 & +67 & 1.06 \\
GFDL & +5.5 & +8.4 & +5.5 & +6.0 & -3 & +125 & 0.25 \\
Hadley & +1.8 & +2.6 & +2.6 & +2.6 & +26 & +201 & 0.57 \\
UKMO & +8.9 & +6.6 & +7.9 & +7.0 & +15 & +347 & 0.34 \\
CCC & +5.0 & +4.7 & +5.4 & +5.1 & +3 & +253 & 0.29 \\
Current & $-2.0^{\circ} \mathrm{C}$ & $21.8^{\circ} \mathrm{C}$ & $10.3^{\circ} \mathrm{C}$ & $18.9^{\circ} \mathrm{C}$ & $1072 \mathrm{~mm}$ & $54 \mathrm{~mm}$ & 1.34 \\
\hline
\end{tabular}

operate closer to the terminal nodes of the regression tree (M ichaelsen et al. 1994). Further details on model development and validation can be found in Iverson \& Prasad (1998). Species' maps and data on environmental relationships are available in an atlas (Iverson et al. 1999a) and on the web (Prasad \& Iverson 1999). M odels for 75 tree species in the MAR were used in our analysis.

To predict potential future suitable habitat for each species, the predictive models were applied, substituting values of current climate with those computed from each of the 5 GCM scenarios. (Climate variables in the models are those shown in Table 1.) The output obtained was the average importance value for each species, for each county, and for each GCM scenario. These values were used to calculate a $\sum$ IV $\times$ area score (hereafter, IV $\times$ area score) for each species and GCM scenario, calculated as the sum of the IV $\times$ county area for each county in which the species was present (i.e., IV above a minimum level of 3.0). We converted these data outcomes to estimates of potential change from current conditions.

Using these predicted importance values, forest type maps were constructed for current conditions and for each GCM scenario, based on rules developed to sum IV s for key species associated with particular forest types. Species were assigned to a forest type based on the USDA Forest Service classification according to Hansen et al. (1992), as shown in Table 2. Each county was scored for each forest type, and assigned to the type receiving the highest score. Seven forest types are presently recorded from the MAR (see Fig. 1).

The methods used here assume that species will be able to colonize all suitable sites. Time lags in species' migration are not accounted for, nor are competitive interactions among species. Since the models are not physiologically based, they cannot account for enhanced growth or gains in water use efficiency with increased $\mathrm{CO}_{2}$. Neither can the models address potential changes in other aspects of forest dynamics, such as silviculture, insects and disease, invasion of exotics, or land use change.

\subsection{Potential changes in species' importance and forest type}

The IV $\times$ area score incorporates the effect of changing importance and area simultaneously, and thus may

Table 2. Classification scheme used for assigning tree species to a forest type (follows Hansen et al. 1992)

\begin{tabular}{|c|c|}
\hline Forest type & Component species \\
\hline Longleaf/slash pine & Slash pine, longleaf pine \\
\hline Loblolly/shortleaf & Shortleaf pine, loblolly pine, Virginia pine \\
\hline Oak/pine ${ }^{a}$ & $\begin{array}{l}\text { Eastern white pine, shortleaf pine, Virginia pine, } \\
\text { northern red oak, southern red oak, loblolly pine, } \\
\text { water oak, willow oak, post oak, scarlet oak }\end{array}$ \\
\hline Oak/hickory & $\begin{array}{l}\text { Hickory, bitternut hickory, pignut hickory, shag- } \\
\text { bark hickory, mockernut hickory, white oak, } \\
\text { scarlet oak, chestnut oak, northern red oak, post } \\
\text { oak, black oak, sweetgum, tulip tree }\end{array}$ \\
\hline Oak/gum/cypress & $\begin{array}{l}\text { Swamp red oak, willow oak, sweetgum, American } \\
\text { elm, baldcypress, pond cypress, red maple, water } \\
\text { tupelo, swamp tupelo }\end{array}$ \\
\hline Elm/ash/cottonwood & $\begin{array}{l}\text { Red maple, American elm, black ash, white ash, } \\
\text { sycamore, eastern cottonwood, willow, black } \\
\text { willow }\end{array}$ \\
\hline Maple/beech/birch & $\begin{array}{l}\text { Red maple, sugar maple, American beech, yellow } \\
\text { birch, black cherry, black walnut }\end{array}$ \\
\hline \multicolumn{2}{|c|}{$\begin{array}{l}\text { a An additional rule set was needed for the oak/pine forest type, because it } \\
\text { was the sum of many major oaks and pines, yet the class was intended for } \\
\text { counties with mixtures of at least } 50 \% \text { oak and } 25 \text { to } 50 \% \text { pine species } \\
\text { (Merz 1978). For this, if the above algorithm determined the class to be } \\
\text { oak/pine, the following statements were applied: (1) if the loblolly/shortleaf } \\
\text { class was greater than the oak/hickory class } 6 \text {, the county was reclassified } \\
\text { to loblolly/shortleaf, because the pine component is }>50 \% \text {; }(2) \text { if the oak/ } \\
\text { hickory class was greater than twice that of the loblolly/shortleaf class, the } \\
\text { county was reclassified to oak/hickory, because there was likely less than a } \\
25 \% \text { pine component; ( } 3 \text { if if neither of the above applied, the county re- } \\
\text { mained classed as oak/pine }\end{array}$} \\
\hline
\end{tabular}


Table 3. Current IV $\times$ area score (computed from Forest Inventory and A nalysis [FIA] data), percent change in the IV $\times$ area score under each of 5 GCM scenarios, and average percent change in the IV $\times$ area score across GCM scenarios for the 42 most important (current or future IV $\times$ area score above an arbitrary cut-off value) tree species in the MAR

\begin{tabular}{|c|c|c|c|c|c|c|c|c|}
\hline \multirow[t]{2}{*}{ Species } & \multirow[t]{2}{*}{ Common name } & \multirow{2}{*}{$\begin{array}{l}\text { Current IV } \times \\
\text { area score } \\
\quad\left(\times 10^{6}\right)\end{array}$} & \multicolumn{6}{|c|}{ Percent change in IV $\times$ area score } \\
\hline & & & GISS & GFDL & Hadley & $\mathrm{CCC}$ & UKMO & $\begin{array}{c}\text { Average } \\
\text { GCM }\end{array}$ \\
\hline Populus tremuloides & Quaking aspen & 0.50 & -100 & -100 & -96 & -100 & -100 & -99 \\
\hline Acer saccharumb & Sugar maple & 4.18 & -95 & -100 & -100 & -100 & -100 & -99 \\
\hline Betula alleghaniensis & Yellow birch & 0.52 & -92 & -100 & -86 & -100 & -100 & -96 \\
\hline Fagus grandifoliab & American beech & 3.15 & -84 & -84 & -84 & -84 & -84 & -84 \\
\hline Crataegus sp. ${ }^{a}$ & Hawthorn & 1.05 & -77 & -78 & -83 & -78 & -78 & -79 \\
\hline Prunus serotina ${ }^{b}$ & Black cherry & 3.84 & -77 & -78 & -78 & -78 & -78 & -77 \\
\hline Acer rubrum & Red maple & 10.40 & -50 & -82 & -85 & -82 & -84 & -77 \\
\hline Acer pensylvanicum & Striped maple & 0.65 & -73 & -78 & -39 & -72 & -79 & -68 \\
\hline Tsuga canadensis & Eastern hemlock & 1.36 & -65 & -65 & -57 & -65 & -65 & -63 \\
\hline Fraxinus americana & White ash & 2.88 & -62 & -80 & -13 & -61 & -97 & -63 \\
\hline Pinus strobus ${ }^{a}$ & Eastern white pine & 1.37 & -61 & -68 & -42 & -63 & -68 & -60 \\
\hline Quercus rubra & Northern red oak & 2.89 & -48 & -62 & -26 & -59 & -95 & -58 \\
\hline Pinus virginiana ${ }^{a}$ & Virginia pine & 1.69 & -10 & -89 & -39 & -39 & -80 & -51 \\
\hline J uglans nigra & Black walnut & 0.47 & -49 & -57 & -19 & -46 & -62 & -46 \\
\hline Sassafras al bidum ${ }^{a}$ & Sassafras & 1.49 & -41 & -51 & -35 & -44 & -59 & -46 \\
\hline Ilex opaca & American holly & 0.64 & -47 & -49 & -23 & -47 & -48 & -43 \\
\hline Betula lenta & Sweet birch & 1.53 & -53 & -53 & -15 & -51 & -42 & -43 \\
\hline Robinia psuedoacacia & Black locust & 1.01 & -38 & -49 & -26 & -49 & -52 & -43 \\
\hline Ostrya virginiana ${ }^{a}$ & E. hophornbeam & 0.65 & -53 & -59 & -5 & -49 & -33 & -40 \\
\hline Quercus coccinea & Scarlet oak & 1.19 & -0 & -65 & 0 & -32 & -57 & -31 \\
\hline Fraxinus sp. & Ash & 0.48 & -29 & -0 & -40 & 1 & -21 & -18 \\
\hline Liriodendron tulipifera ${ }^{a}$ & Yellow-poplar & 3.15 & -18 & -24 & -15 & -15 & -15 & -17 \\
\hline Quercus prinus & Chestnut oak & 3.60 & -3 & 5 & -24 & -12 & -24 & -12 \\
\hline Carpinus caroliniana $^{a}$ & American hornbeam & 0.81 & 4 & 15 & -4 & 9 & 10 & 7 \\
\hline Nyssa sylvatica & Black tupelo & 1.89 & 8 & -14 & 42 & -8 & 19 & 9 \\
\hline Ulmus sp. ${ }^{a}$ & Elm & 0.59 & 10 & 10 & 10 & 10 & 10 & 10 \\
\hline Oxydendrum arboreum & Sourwood & 0.78 & 48 & 40 & -28 & 55 & 58 & 34 \\
\hline Carya sp. ${ }^{a}$ & Hickory & 2.36 & 32 & 41 & 14 & 41 & 46 & 35 \\
\hline Cornus florida & Flowering dogwood & 2.20 & 47 & 53 & 24 & 50 & 51 & 45 \\
\hline Quercus alba ${ }^{b}$ & White oak & 3.50 & 25 & 72 & 98 & 64 & 6 & 53 \\
\hline Nyssa biflora & Swamp tupelo & 0.38 & 68 & 70 & 21 & 56 & 68 & 57 \\
\hline Liquidambar styraciflua & Sweetgum & 2.10 & 63 & 79 & 10 & 69 & 91 & 63 \\
\hline Quercus velutina $^{a}$ & Black oak & 1.59 & 53 & 122 & 207 & 101 & -55 & 86 \\
\hline Pinus echinata & Shortleaf pine & 0.37 & 156 & 159 & 130 & 160 & 166 & 154 \\
\hline Pinus taeda & Loblolly pine & 3.05 & 138 & 219 & 20 & 185 & 324 & 177 \\
\hline Quercus falcata var. falcata & Southern red oak & 0.44 & 176 & 251 & 47 & 229 & 436 & 228 \\
\hline Diospyros virginiana $^{a}$ & Persimmon & 0.15 & 247 & 407 & 247 & 406 & 488 & 359 \\
\hline Quercus nigra & Water oak & 0.19 & 862 & 1161 & 336 & 1053 & 1551 & 992 \\
\hline Quercus muehlenbergii & Chinkapin oak & 0.08 & 1281 & 2439 & 770 & 2403 & 3359 & 2051 \\
\hline Quercus stellatab $^{\mathrm{b}}$ & Post oak & 0.18 & 418 & 4329 & 2965 & 4412 & 4427 & 3310 \\
\hline Quercus laurifolia & Laurel oak & 0.05 & 4107 & 4623 & 899 & 3316 & 14881 & 5565 \\
\hline Carya tomentosa ${ }^{\mathrm{b}}$ & M ockernut hickory & 0.05 & 2289 & 7412 & 7412 & 7412 & 7412 & 6388 \\
\hline
\end{tabular}

be the best metric of potential change for species. Table 3 shows the percent change in the IV $\times$ area score for 42 of the most important species in the MAR, ranked according to the average (across all 5 GCMs) percent change. The species shown here are ones whose current or future IV $\times$ area score (average across GCMs) exceeds an arbitrary threshold. The current IV $\times$ area scores, based on FIA data, are also presented to allow better interpretation of the data, since some of the species that undergo potentially large percentage changes are currently uncommon.

There is general agreement among GCMs in the direction of change and, in many cases, the magnitude of change in IV $\times$ area scores (Table 3). If the absolute values of the predicted changes are summed by GCM, the Hadley and GISS scenarios cause the least amount 
of change in tree species importance values, while the UKMO, GFDL and CCC scenarios cause larger changes. (This is true even if some of the largest percent changes are excluded from the computation.) This is in general agreement with the relative magnitude of the climate changes shown in Table 1. For some species, IV $\times$ area scores are remarkably similar across GCM scenarios. In these cases, climate variables appear early in the RTA models to distinguish coarsely between suitable and unsuitable habitat. The RTA technique forces continuous data to follow 1 of 2 discrete branches. Relatively small variations in future climate among scenarios do not al ways mean they will follow different branches.

Of the species that are of economic significance to the region, most could see significant changes in IV. Species that could be enhanced (with their potential percentage change) include Pinus palustris (longleaf pine, $+2893 \%$ ), P. taeda (loblolly pine, $+177 \%$ ), P. echinata (shortleaf pine, $+154 \%$ ), and Quercus alba (white oak, $+53 \%$ ). Important species subject to reduction include Acer saccharum (sugar maple, - 99\%), Prunus serotina (black cherry, - 77\%), Q. rubra (N orthern red oak, $-58 \%$ ), and Liriodendron tulipifera (tuliptree, $-17 \%$ ) (Table 3). These changes could significantly alter the economic and aesthetic resources of the region.

Of the total 75 tree species that were considered from the MAR, 37 species could be reduced in overall importance under climate change. Of these, 20 species could be reduced by at least $50 \%$ and 8 could be reduced by at least $90 \%$. On the other hand, 33 species could be enhanced, with 22 increasing at least $50 \%$ including 15 species that could at least double in importance. Seven species could increase by more than 20-fold.

$M$ any of the species showing a large percentage increase in their IV $\times$ area score (e.g., Carya tomentosa [mockernut hickory, $+6388 \%$ ], Quercus laurifolia [laurel oak, $+5565 \%$ ]) are currently uncommon in the MAR (see current IV $\times$ area score in Table 3 ). Percentages alone can therefore be misleading if not interpreted in conjunction with the current status of the species. Species potentially undergoing the largest absolute increases in IV $\times$ area score include Q. stellata, Pinus taeda, Ulmus alata, Q. falcata var. falcata, P. palustris, and P. ellotti. These species currently tend to thrive in warmer climates, and their predicted increase in importance represents a potential northward migration. Species potentially undergoing large absolute decreases in IV $\times$ area score are more representative of species preferring cooler, moister habitats, and include Acer rubrum, A. saccharum, Prunus serotina, Fraxinus americana, Q. rubra, and Fagus grandifolia.
Forest type maps for each of the climate scenarios (Fig. 2) suggest that dramatic changes could occur following climate change. The potential large increases in 3 species of pine-Pinus echinata, P. taeda, and P. palustris-greatly influence the potential forest type outcomes by enhancing the longleaf-slash pine, loblolly-shortleaf pine, and oak-pine types under most GCM scenarios. Compared to today, large increases could also occur within the oak-hickory type (and the oak-pine type) as 10 species of oak could increase by at least 50\% (Table 3).

On the other hand, 2 forest types could be severely reduced or eliminated following climate change: elmash-cottonwood and maple-beech-birch (Fig. 2). Though most individual tree species from these forest types would remain, their importance could be greatly diminished relative to the pines and oaks. For example, the primary elements (and their potential changes from Table 3) in the maple/beech/birch type are Acer rubrum $(-77 \%)$, A. saccharum (-99\%), Fagus grandifolia $(-84 \%)$, Betula alleghaniensis (yellow birch, $-96 \%)$, Prunus serotina $(-77 \%)$, and Juglans nigra (black walnut, $-46 \%$ ).

The GCM scenarios with the most severe temperature change (UKMO, GFDL, CCC) show the oakpine forest type advancing farther to the north and east than the 2 more benign climate scenarios (Hadley and GISS) (Fig. 2). The intrusion of the oakpine type is most pronounced for UKMO - the climate scenario with the highest temperatures during the growing season and on a mean annual basis. Small areas of maple-beech-birch and elm-ash-cottonwood forest remain under the GISS scenario only, most likely a reflection of the fact that one of the constituent species of both of these forest types, Acer rubrum (Table 3), is less severely affected by the GISS scenario. Loblolly-shortleaf pine forest is most abundant under the GISS scenario. In this case, the oak species generally show proportionately less increase as compared to the other GCM scenarios, and pines more often dominate in a particular county.

\section{IM PACTS OF EXTREME WEATHER EVENTS ON FOREST LAND MANAGEMENT}

\subsection{Survey purpose and methodology}

Most past research has focused on the long-term impacts of changing temperature and precipitation regimes on forests based on GCM predictions expressed as mean monthly or annual values (e.g., VEMAP members 1995, McNulty et al. 1996, Shugart $\&$ Smith 1996). Much less attention has been given 

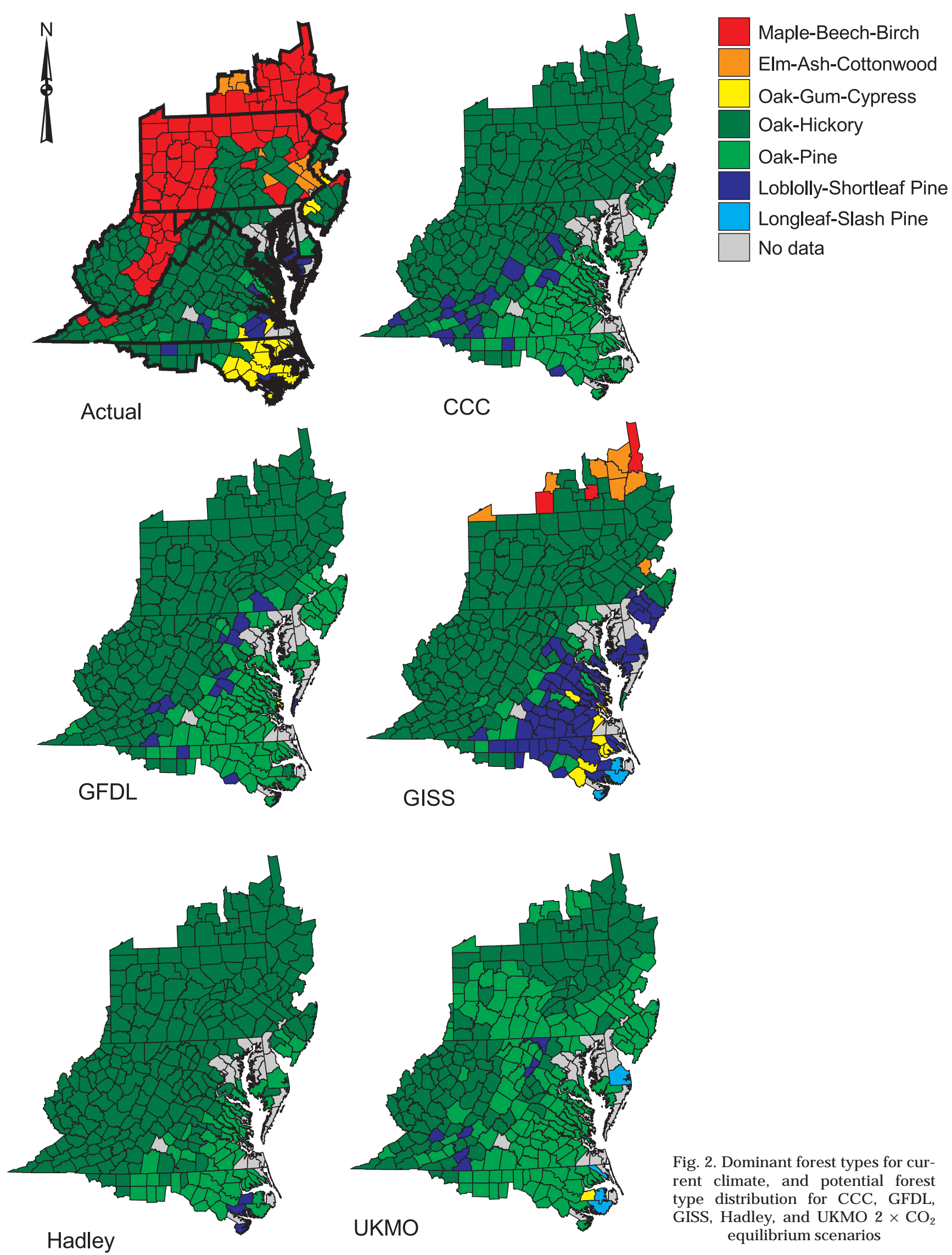

Fig. 2. Dominant forest types for current climate, and potential forest type distribution for CCC, GFDL, GISS, Hadley, and UKMO $2 \times \mathrm{CO}_{2}$ equilibrium scenarios 
to how climate change will affect the frequency and intensity of extreme events and how these changes will, in turn, affect forest land management. Examining the impacts of current climate variations can provide insight into the types of climatic events that are most problematic in the MAR now, and help us to anticipate the impacts of future climate change.

Because little specific information was available on how climate variability currently affects forestry activities in the MAR, we developed, pre-tested, and revised a questionnaire to investigate how extreme weather affects day-to-day forestry operations. The questionnaire targeted government agencies (federal and state), private firms (consulting foresters, loggers, and industrial foresters), and urban and municipal foresters within the MAR. The questions were designed to obtain information about effects of extreme weather on specific aspects of forestry operations, coping mechanisms currently being employed or contemplated, and effects on costs of operation and income. The results presented here focus on the impacts of various types of severe weather events, and differences in weather impacts between upland hardwood versus Southern pine forestry operations. We then relate these impacts to projections of potential shifts in species composition due to long-term changes in climate.

Questionnaires were sent to government and private forestry offices/agencies/firms in the MAR based upon lists compiled from contacts with management agencies in each state. All government and large industrial forestry offices/agencies/firms identified were sent questionnaires. To make the sample size more manageable (yet still yield useful data), questionnaires also were mailed to a random sample of the loggers, sawmill operators and consulting foresters in the region. A preliminary survey of 30 firms was used to help determine the size of the random sample needed and to improve the questionnaire.

A total of 592 surveys were mailed in late November 1998 followed by a second mailing to non-respondents in J anuary 1999. A total of 322 surveys were returned, yielding an overall response rate of $57 \%$ after correction for erroneous addresses. M ost respondents represented private forestry firms (159 consulting foresters, logging companies, and industrial foresters) or public forestry agencies (114 state and federal agencies/ offices). Of the total respondents, $66 \%$ operate in the hardwood forest types, while $22 \%$ operate only within the Southern pine types. Chi-squared tests using 2-way classifications and an $\alpha=0.05$ (Noether 1991) were used to test for significant differences in the distributions of responses ( $1=$ no impact to $5=$ major impact) for upland hardwoods versus Southern pine groups.

\subsection{Survey results}

Overall, extreme weather events have had a low to moderate impact on forestry activities in the MAR over the past $10 \mathrm{yr}$ (Fig. 3). Respondents rated events with heavy rainfall, ice storms and high winds as causing the most problems over the past decade. Over $20 \%$ of the respondents ranked these 3 types of severe weather events as having a major impact (rank $=5$ ) on their operations. This is consistent with the occurrence of major hurricane/tropical depression events (Hugo, Bertha, and Fran) and associated high winds and heavy rain in the southern portion of the region over the past $10 \mathrm{yr}$, and a major ice storm in the northern portion of the region in 1998 (USDA Forest Service 1998). Lesser impacts were associated with low rainfall, heavy snow, and periods with extreme high and low temperatures, but all types of events showed mean impacts well above zero (mean rank $>2$ ).

The impacts of severe weather on forest land management were generally similar for Southern pine and hardwood regions (Fig. 3), with one exception. Heavy snows-which are quite uncommon in the southern part of the region - were obviously not as great a problem for the Southern pine operations. Other differences between hardwood and Southern pine operations were not statistically significant. Despite the fact that hurricane or tropical depression impacts are more likely in the Southern pine areas, high winds were rated similarly for both hardwood and pine operations. M ajor impacts of each type of severe weather on forest land management related strongly to effects on accessibility to forest land, direct damage to trees, and increased problems with insects, disease and fire (Table 4). The rankings of the types of impacts were remarkably consistent between the hardwood and Southern pine

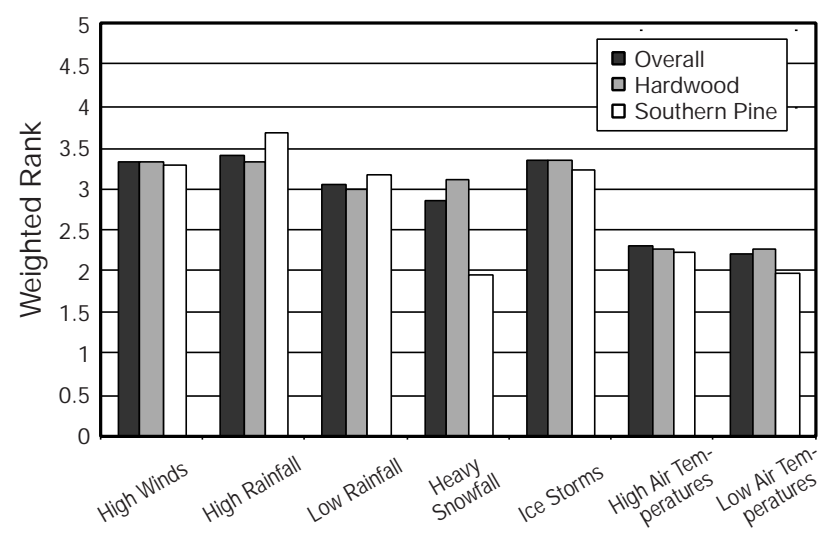

Fig. 3. Weighted mean rank of the impact of various types of extreme weather events on forest land management in the MAR for all, hardwood and Southern pine forestry operations based upon a 1999 questionnaire survey (rank: $1=$ no impact, 3 =moderate impact, 5 =major impact) 
Table 4. M ajor forestry problems caused by various types of severe weather in the MAR over the past decade

\begin{tabular}{|lll|}
\hline Weather type & Highest ranked impact & Second-highest ranked impact \\
\hline High winds & Direct damage to trees & Creation of an unsafe work environment \\
High rainfall & $\begin{array}{l}\text { Limited access due to flooding and muddy } \\
\text { conditions }\end{array}$ & $\begin{array}{l}\text { Increased maintenance costs for roads, yards, } \\
\text { landings }\end{array}$ \\
Low rainfall & Improved access & Tree mortality \\
Heavy snow and ice & Direct damage to trees by ice and snow loading & Limited access due to deep snow \\
Extreme temperatures & Increased insect and disease problems & Tree mortality or increased fires \\
& & \\
\end{tabular}

regions, again except for obvious differences related to geography and snow.

Climate change is expected to increase severe weather occurrences in the MAR, but the specific nature and magnitude of these changes are difficult to predict at this time. Based upon predicted precipitation variations, 'storminess' is expected to increase by 48 to $64 \%$ by 2095 in the M AR, but the reliability of this prediction is considered to be low (Fisher et al. 1999). Several other studies have suggested that climate change will lead to increased frequency of extreme events (Noda \& Tokiola 1989, Mitchell \& Ingram 1990, Changnon \& Changnon 1992, Karl et al. 1995), but again the certainty of the predictions is quite low and not specific to the MAR. By 2095, based on transient runs of $2 \mathrm{GCMs}$, the region's air temperatures are predicted to increase by 2.7 to $5.6^{\circ} \mathrm{C}$ and precipitation is expected to increase by about 6 to $24 \%$ (Fisher et al. 1999). Such warming suggests that heavy snowfall events will decrease in the MAR, and that the geographic distribution of ice storms may migrate northward. Increased storminess would likely generate more high rainfall and high wind events. The impact of climate change on the occurrence of hurricanes, which can have major impacts on forestry in the M AR, is very poorly understood (Walsh \& Pittock 1998).

The types of impacts experienced currently by forest land managers in the MAR, coupled with the expected changes in climate, can be used to make preliminary estimates of climate change impacts on forestry operations. Increased air temperatures suggest that the frequency of limited access due to deep snow and tree damage due to severe icing events would decrease in the region. However, increases in rainfall and storminess suggest greater problems with forest land access due to mud and flooding and increased maintenance costs. General increases in storminess could also increase direct wind damage to forests and create related problems with periodic variations in market prices for timber products (Quine et al. 1995). Higher temperatures combined with low rainfall would cause more frequent drought conditions, which may lead to more problems with insects, disease and fire in the region than currently experienced. The similarity of responses from Southern pine and hardwood sectors of the M AR suggests that changes in species distributions due to climate change would not alone lead to major changes in the importance of severe weather. One possible exception is that expansion of Southern pine species in the region would likely increase problems associated with direct wind and ice damage to trees due to persistent foliage.

Overall, given that extreme weather is currently having only a low to moderate impact on forest land management in the region, the net effect of future changes in extreme weather is likely to be modest, on average. However, impacts are likely to vary spatially, so that some areas may be severely impacted while others escape harm. Since climate change may affect the magnitude, periodicity, duration and co-occurrence of extreme events, our ability to extrapolate from past experience is somewhat limited. Results will also be influenced by the extent to which the last decade provides a representative sample of extreme weather events. In spite of these limitations, the survey approach has provided a means of making a relatively rapid assessment of the impacts of extreme weather events, based on past experience, that can be used to provide insight into possible future impacts.

\section{SUMMARY AND CONCLUSIONS}

We have examined the impacts of climate on MidAtlantic forests from 2 different perspectives. First, from an ecological perspective, we looked at the potential impacts of future climate change on potential tree species' distribution and importance using statistical models that relate tree species distributions to environmental variables, including climate. The tree modeling suggests a great potential for redistribution of tree species in the MAR as a result of climate change. Most prominent are the potentially very large increases in several species of oak and pine, resulting in a dominance of the forest types containing these species. These species tend to be better adapted to the 
hotter and dryer conditions projected by the GCM scenarios. On the other hand, the forest species and types that are better suited to moist conditions could potentially suffer severe reductions. For example, the elmash-cottonwood and maple-beech-birch types could eventually lose their prominence in the region. These results are broadly consistent with those of the VEM AP study (VEMAP members 1995), where results generally show warm-temperate mixed forest/evergreen forest moving northward, displacing temperate deciduous forest in the southern part of the MAR, and cooltemperate mixed forest (such as maple-beech-birch) disappearing completely from the region.

Further research is needed to determine the extent to which the potential changes in distribution predicted here will be realized. This will be influenced by species' ability to migrate through a fragmented habitat. Work in this area is underway (Iverson et al. 1999b). Other factors that warrant further investigation are the potential secondary impacts of climate change, such as the increased incidence of insects, disease and fire-factors that were identified as important by our survey respondents. Current MARA research is addressing some of these secondary impacts.

Second, we used a survey to gather information on the types of extreme weather events that are currently problematic for forest land managers, and the types of impacts they cause to forests and forestry operations. Respondents indicated that high winds and precipitation-related events have been more problematic than extreme temperatures alone, based on experiences over the past decade. Types of major impacts include operational impacts (in particular, altered access to forest areas) as well as structural impacts (direct damage to trees) and biological impacts (mortality, and increased problems with insects, disease and fire). This information, in conjunction with our results from the tree species distribution modeling, was used to make inferences about the potential impacts of extreme events in the future. We note that climate change may lead to alterations in the frequency, severity and duration of extreme events such that the past is an imperfect predictor of the future.

Future MARA research will use results from the survey and tree modeling work to examine the economic consequences of climate-change-related impacts on forests in the MAR. Some preliminary findings are described in Rose et al. (2000).

Acknowledgements. Work by L.R.I. and A.M.P. was supported by the USDA Forest Service Northern Global Change Program (Rich Birdsey, Program M anager). Thanks go to Ron Neilson and Ray Drapek for providing GCM scenario data used in this study. We also thank the numerous members of the MARA advisory committee who reviewed previous de- scriptions of this work, and the anonymous reviewers for their constructive comments. Support for the MARA is being provided by the US Environmental Protection Agency and various units at The Pennsylvania State University.

\section{LITERATURE CITED}

Aber JD, Ollinger SV, Federer CA, Reich PB, Goulden ML, Kicklighter DW, Melillo J M, Lathrop RG (1995) Predicting the effects of climate change on water yield and forest production in the northeastern US. Clim Res 5:207-222

Auclair AND, Lill JT, Revenga C (1996) The role of climate variability and global warming in the dieback of northern hardwoods. Water Air Soil Pollut 91:163-186

Bazzaz FA (1990) The response of natural ecosystems to the rising global $\mathrm{CO}_{2}$ levels. Annu Rev Ecol Syst 21:167-196

Bazzaz FA, Coleman J S, M orse SR (1990) Growth responses of seven major co-occurring tree species of the northeastern United States to elevated $\mathrm{CO}_{2}$. Can J For Res 20: 1479-1484

Changnon SA, Changnon J M (1992) Temporal fluctuations in weather disasters: 1950-1989. Clim Change 22:191-208

Clark LA, Pergibon D (1992) Tree-based models. In: Chambers J M, Hastie TJ (eds) Statistical models. S Wadsworth, Pacific Grove, CA, p 377-419

Eamus D (1996) Responses of field grown trees to $\mathrm{CO}_{2}$ enrichment. Commonwealth For Rev 75:39-47

Fisher A, and 12 others (1999) Preparing for a changing climate: the potential consequences of climate variability and change-Mid Atlantic draft. Prepared for USGCRP First National Assessment, sponsored by US Environmental Protection Agency, Cooperative Agreement No. CR 826554-01

Hansen J , Fung I, Lacis A, Rind D, Lebedeff S, Ruedy R (1988) Global climate changes as forecast by Goddard Institute for Space Studies three-dimensional model. J Geophys Res 93:9341-9364

Hansen M H, Frieswyk T, Glover J F, Kelly J F (1992) The Eastwide Forest Inventory data base: user's manual. General Technical Report NC-151, US Department of Agriculture, Forest Service, North Central Forest Experiment Station, St. Paul, M N

IPCC (1996) Climate change 1995: impacts, adaptations, and mitigation of climate change: scientific-technical analysis. Contribution of Working Group II to the second assessment report of the Intergovernmental Panel on Climate Change. Watson RT, Zinyowera M C, M oss RH (eds) Cambridge University Press, New York

IPCC (1998) The regional impacts of climate change: an assessment of vulnerability. A special report of the Intergovernmental Panel on Climate Change Working Group II. Watson RT, Zinyowera MC, Moss RH (eds) Cambridge University Press, New York

Iverson LR, Prasad AM (1998) Predicting abundance of 80 tree species following climate change in the eastern United States. Ecol M onogr 68(4):465-485

Iverson LR, Prasad AM, Scott CT (1996) Preparation of forest inventory and analysis (FIA) and state soil geographic data base (STATSGO) data for global change research in the eastern United States. In: Hom J , Birdsey R, O'Brian K (eds) Proceedings, 1995 meeting of the Northern Global Change Program. General Technical Report NE-214, USDA Forest Service, Northeastern Forest Experiment Station, Radnor, PA, p 209-214

Iverson LR, Prasad AM, Hale BJ, Sutherland EK (1999a) An atlas of current and potential future distributions of com- 
mon trees of the eastern United States. General Technical Report NE-265, Northeastern Research Station, USDA Forest Service, Delaware, $\mathrm{OH}$

Iverson LR, Prasad AM, Schwartz MW (1999b) Modeling potential future individual tree-species distributions in the Eastern United States under a climate change scenario: a case study with Pinus virginiana. Ecol Model 115:77-93

Karl RK, Knight RW, Plummer N (1995) Trends in high-frequency climate variability in the twentieth century. Nature 377:217-220

Kattenberg A, Giorgi F, Grassl H, Meehl G, Mitchell J FB, Stouffer RJ, Tokioka T, Weaver AJ, Wigley TML (1996) Climate models- projections of future climate. In: Houghton JT, Meira Filho LG, Callander BA, Harris N, Kattenberg A, Maskell K (eds) Climate change 1995-the science of climate change. Contribution of Working Group I to the second assessment report of the Intergovernmental Panel on Climate Change. Cambridge University Press, New York, p 285-357

Laprise R, Caya D, Giguère M, Bergeron G, Côté H, Blanchet J P, Boer GJ, McFarlane N (1998) Climate and climate change in Western Canada as simulated by the Canadian Regional Climate M odel. Atmos-Ocean 36:119-167

McNulty SG, Vose J M, Swank WT (1996) Potential climate change effects on loblolly pine forest productivity and drainage across the southern United States. Ambio 25(7): 449-453

M elillo J FB, M cGuire AD, Kicklighter DW, M oore B III, Vorosmorty CJ, Schloss AL (1993) Global climate change and terrestrial net primary production. Nature 363:234-240

Merz RW (compiler) (1978) Forest atlas of the Midwest North Central Forest Experiment Station. USDA Forest Service, St. Paul, M N

Michaelsen J , Schimel DS, Friedl M A, Davis FW, Dubayah RC (1994) Regression tree analysis of satellite and terrain data to guide vegetation sampling and surveys. J Veg Sci 5: 673-686

Mitchell J FB, Ingram WJ (1990) Mechanisms of changes in cloud. J Clim 5:5-21

Mitchell J FB, J ohns TC, Gregory J M, Tett S (1995) Climate response to increasing levels of greenhouse gases and sulphate aerosols. Nature 376:501-504

Noda A, Tokiola T (1989) The effect of doubling $\mathrm{CO}_{2}$ concentration on convective and nonconvective precipitation in a general circulation model coupled with a simple mixed layer ocean. J Meteorol Soc J pn 67:95-110

Noether GE (1991) Introduction to statistics, the nonparametric way. Springer-Verlag, New York

Pastor J , Post WM (1988) Response of northern forests to $\mathrm{CO}_{2}$ induced climate change. Nature 334:55-58

Pitelka LF and the Plant Migration Workshop Group (1997) Plant migration and climate change. Am Sci 85:464-473

Powell DS, Faulkner J L, Darr DR, Zhu Z, MacCleery DW (1994) Forest resources of the United States, 1992. USDA
Forest Service, Rocky M ountain Forest and Range Experiment Station, General Tech Report, RM-234 (Revised)

Prasad AM, Iverson LR (1999) A climate change atlas for 80 forest tree species of the eastern United States [spatial database]. Northeastern Research Station, USDA Forest Service, Delaware, OH (accessed: October 1999) available at http://www.fs.fed.us/ne/delaware/4153/atlas/index. html

Quine C, Coutts M, Gardiner B, Pyatt G (1995) Forests and wind: management to minimize damage. Bull 114, HMSO, London

Rose A, Cao Y, Oladosu G (2000) Simulating the economic impacts of climate change in the Mid-Atlantic Region. Clim Res 14:175-183

Shugart HH, Smith TM (1996) A review of forest patch models and their application to global change research. Clim Change 34(2):131-153

Soloman AM (1986) Transient response of forests to $\mathrm{CO}_{2}$ induced climate change: simulation modeling experiments in eastern North America. Oecologia 68:567-579

Soloman AM , Kirilenko AP (1997) Climate change and terrestrial biomass: what if trees do not migrate? Global Ecol Biogeogr Lett 6:139-148

USDA Forest Service (1998) Ice storm 1998: cooperating for forest recovery. Northeastern A rea and Private Forestry, USDA Forest Service

US EPA (1993) EPA-Corvallis model-derived climate database and $2 \times \mathrm{CO}_{2}$ predictions for long-term mean monthly temperature, vapor pressure, wind velocity and potential evapotranspiration from the Regional Water Balance Model and precipitation from the PRISM model, for the conterminous United States. Digital raster data on a $10 \times$ 10 km, $470 \times 295$ Albers Equal Area grid, in 'Image Processing Workbench' format. US Environmental Protection Agency, Environmental Research Laboratory, Corvallis, OR

US EPA (1997) An ecological assessment of the United States Mid-Atlantic Region: a landscape atlas. Document \#EPA/ 600/R-97/130, US Environmental Protection Agency, Office of Research and Development, Washington, DC

VEMAP members (1995) Vegetation/ecosystem modeling and analysis project: comparing biogeography and biogeochemistry models in a continental-scale study of terrestrial ecosystem responses to climate change and $\mathrm{CO}_{2}$ doubling. Global Biogeochem Cycles 9(4):407-437

Walsh K, Pittock AB (1998) Potential changes in tropical storms, hurricanes, and extreme rainfall events as a result of climate change. Clim Change 39:119-213

Wetherald RT, M anabe S (1988) Cloud feedback processes in a general circulation model. J Atmos Sci 45:1397-1415

Wilson CA, Mitchell J FB (1987) A doubled $\mathrm{CO}_{2}$ climate sensitivity experiment with a global climate model including a simple ocean. J Geophys Res 92(D11):13315-13343

Woodward FI (1987) Climate and plant distribution. Cambridge University Press, Cambridge 